\title{
REPRESENTAÇÕES DE LICENCIANDOS ACERCA DAS TEORIAS DA APRENDIZAGEM E SUAS RELAÇÕES NA PRÁTICA DE ENSINO EM CIÊNCIAS/BIOLOGIA: O CONCEITO DE GENE EM FOCO
}

\author{
RODRIGUES, Fernanda Fernandes dos Santos ${ }^{1 *}$; PEREIRA, Boscolli Barbosa ${ }^{1 * *}$ \\ ${ }^{1}$ Universidade Federal de Uberlândia \\ fernandabio63@hotmail.com* \\ boscolli86@hotmail.com**
}

\section{RESUMO}

A equivocada leitura das teorias de aprendizagem no contexto da formação de professores tem não somente banalizado seus conceitos, mas influenciado a prática docente para uma exaustiva utilização de estratégias de ensino centradas unicamente no aluno. O presente trabalho buscou conhecer as representações de licenciandos em relação às teorias de aprendizagem e como elas influenciam a prática pedagógica. A coleta de dados foi organizada em quatro situações, em ordem, a saber: i) classificação do nível de adequação das teorias de aprendizagem em relação à formulação do conceito de "gene" apresentado; ii) elaboração de plano de aula para o ensino do conceito de gene; iii) definição pessoal de educação construtivista; iv) elaboração de plano de aula, segundo a teoria construtivista, para o ensino do conceito de gene. Os resultados revelaram que a maioria dos discentes apresenta representações sobre as teorias de aprendizagem que culminam numa prática de caráter empirista.

PALAVRAS-CHAVE: Formação docente. Ensino de Ciências. Pluralismo metodológico. Prática de ensino. Epistemologia.

\section{UNDERGRADUATES REPRESENTATIONS ABOUT THE LEARNING THEORIES AND RELATIONS IN TEACHING PRACTICE IN SCIENCE/BIOLOGY: FOCUS ON GENE CONCEPT}

\begin{abstract}
The misreading of learning theories in the context of teacher education has not only trivialized their concepts, but influenced the teaching practice for extensive use of teaching strategies focused solely on the student. This study aimed to analyze the representations of undergraduates in relation to learning theories and how they influence the pedagogical practice. Data collection was organized in four situations, in order, namely: i) classification of the adequacy

of learning theories regarding the concept formulation "gene" presented; ii) development of lesson plan for teaching the concept of gene; iii) personal definition of constructivist education; iv) preparation of lesson plan, according to the constructivist theory to the teaching of the gene concept. The results revealed that the majority of students presents representations of the learning theories that culminate an empiricist character of practice.

KEYWORDS: Teacher education. Science teaching. Methodological pluralism. Teaching practice. Epistemology.

\section{LAS REPRESENTACIONES DE LOS ESTUDIANTES ACERCA DE LAS TEORÍAS DEL APRENDIZAJE Y SUS RELACIONES EN LA PRÁCTICA DOCENTE EN CIENCIA/BIOLOGÍA: EL CONCEPTO DE GENE EN FOCO}

\section{RESUMEN}

La equivocada interpretación de las teorías del aprendizaje en el contexto de la formación del profesorado no solo ha trivializado sus conceptos, pero ha influido en la práctica de la enseñanza para el uso extensivo de las estrategias de enseñanza centradas únicamente en el estudiante. Este estudio tuvo como objetivo conocer las representaciones de licenciandos en relación a las teorías del aprendizaje y cómo influyen en la práctica pedagógica. La recolección de datos se organizó en cuatro situaciones, a saber: i) la clasificación de la adecuación de las teorías del aprendizaje del concepto de formulaciones "gen" presentado; ii) la preparación del plan de lecciones para enseñar el concepto de gen; iii) la definición personal de la educación constructivista; iv) la preparación del plan de clase, de acuerdo con la teoría constructivista de la enseñanza del concepto de gen. Los resultados revelaron que la mayoría de los estudiantes muestra representaciones de las teorías del aprendizaje que culminan en una práctica de carácter empírico.

PALABRAS CLAVE: Formación del profesorado. Enseñanza de Ciencias. Pluralismo metodológico. Práctica docente. Epistemología. 


\section{INTRODUÇÃO}

Os currículos de Ciências apresentam, ao menos de forma implícita, contribuições da epistemologia, o que possibilita aos professores uma melhor compreensão da Ciência que ensinam, fundamentando sua ação pedagógica/didática de forma direta.

No entanto, o que transparece nos episódios de ensino das Ciências são concepções incoerentes de natureza empirista e indutivista, que, para um professor conhecedor da orientação epistemológica da educação em Ciência, estão afastadas das teorias, discussões e contribuições atuais (PRAIA; CACHAPUZ; GIL-PÉREZ, 2002).

As críticas contemporâneas à visão empirista-indutivista de Ciência, embora apresentem distintas interpretações da dimensão epistemológica do processo, acumulam-se e permitem reconhecer um acordo entre os principais filósofos e historiadores da Ciência. Nessa perspectiva de crítica ao empirismo, Thomas Kuhn, Karl Popper, Imre Lakatos e Paul Karl Feyerabend negam a concepção de Ciência como resultante de uma produção de conhecimento linear e cumulativa, a qual revela a realidade dos fenômenos a partir, única e exclusivamente, da observação dos mesmos.

O modelo kuhniano, por exemplo, toma o desenvolvimento científico como uma sequência de períodos de Ciência normal, caracterizados pela adesão a um paradigma. Segundo esse modelo, as rupturas com os períodos de Ciência normal só ocorrem mediante revoluções científicas, marcadas pelo surgimento de anomalias no paradigma em vigor (OSTERMANN, 1996).

No racionalismo crítico de Popper, o conhecimento é considerado como falível, corrigível e provisório, de maneira que a refutabilidade demarca a Ciência da não Ciência, sendo que é a falseabilidade das teorias que as aprimoram como científicas (SILVEIRA, 1996a).

Por outro lado, a metodologia dos programas de pesquisa é apresentada como a visão epistemológica de Ciência para Lakatos. Segundo essa perspectiva, as teorias científicas possuem um núcleo firme, irrefutável, protegido por um cinturão. Os programas de pesquisa podem ser progressivos ou regressivos, quando corroborados por fatos novos ou não, respectivamente, de maneira que é a superação dos programas em concorrência, por meio de revoluções científicas, que move a Ciência (SILVEIRA, 1996b). 
Feyerabend critica o racionalismo e apresenta o pluralismo metodológico como opositor a um princípio único, absoluto e imutável de ordem, não sendo contra os procedimentos e métodos, mas contra a universalidade das regras aceitas e válidas como verdadeiras (REGNER, 1996).

Esses filósofos e historiadores da Ciência têm sustentado a oposição suprema dos fenômenos como objeto do conhecimento, de maneira que, devidamente consideradas as concepções desses autores, é possível compreender que a apropriação de conhecimentos científicos pelos alunos ocorre a partir de suas interações com os objetos do conhecimento, a qual algumas vezes tem sido equivocadamente denominada como construtivista.

Já o construtivismo, segundo Moretto (1999, p. 42), “[...] se apresenta como uma corrente epistemológica que renuncia à objetividade tal qual é proposta nas epistemologias empirista, realista e racionalista [...]", de sorte que não é negada a existência de um mundo de objetos que constituem o meio onde vive o homem, mas é proposto que o conhecimento desses objetos decorre da construção do sujeito, não estando, portanto, diretamente acessível. No entanto, Matthews (2000) afirma que o construtivismo tornou-se parte da ortodoxia educacional, pois, embora tenha surgido como uma teoria de aprendizagem, tem se expandido como teoria que rege o ensino, tornando-se uma versão de teoria unificada para a educação.

Nesse sentido, o presente trabalho buscou responder, por meio da retomada de discussões, críticas e contribuições acerca das teorias da aprendizagem, na problemática da formação de professores de Ciências e Biologia, ao seguinte questionamento: Quais as representações dos licenciandos do Curso de Ciências Biológicas em relação às teorias de aprendizagem e como elas influenciam a prática pedagógica no Ensino de Ciências/Biologia?

\section{CAMINHO METODOLÓGICO}

Para o desenvolvimento de nosso trabalho, fundamentamo-nos, do ponto de vista metodológico, na pesquisa de abordagem qualitativa. Segundo Lüdke e André (1986, p. 18), “[...] o estudo qualitativo se desenvolve numa situação natural, é rico em dados descritivos, tem um plano aberto e flexível e focaliza a realidade de forma complexa e contextualizada".

A coleta de dados foi organizada em quatro situações em que os licenciandos deveriam: 1) classificar o nível de adequação das teorias de aprendizagem em relação à formulação do 
conceito de gene apresentado; 2) elaborar um plano de aula para o ensino do conceito de gene; 3) definir educação construtivista; 4) elaborar um plano de aula, segundo a teoria construtivista, para o ensino do conceito de gene.

Para classificar o nível de adequação das teorias de aprendizagem ao objeto de investigação, os licenciandos foram apresentados a um conceito de gene, seguido da apresentação de três modelos representativos das teorias de aprendizagem indutivista, empirista e construtivista, respectivamente.

A Escala Likert foi utilizada como instrumento de mensuração da adequação das teorias de aprendizagem em relação ao processo de elaboração do conceito de gene, segundo as concepções dos licenciandos do Curso de Ciências Biológicas. A Escala Likert foi elaborada de forma a oferecer os seguintes critérios de posicionamento em relação às teorias: 5 = concordo totalmente; 4 = concordo parcialmente; 3 = indiferente; 2 = discordo parcialmente; 1 = discordo totalmente (MARCONI; LAKATOS, 1996).

Para o desenvolvimento do trabalho, foram selecionados os discentes matriculados no último semestre de um curso de licenciatura em Ciências Biológicas. A aplicação dos instrumentos de coleta dos dados foi realizada com 22 discentes no mês de outubro de 2015 .

Os licenciandos foram convidados a responderem aos instrumentos de coleta de dados mediante tomada de ciência do caráter científico do trabalho e da garantia de anonimato de seus nomes, firmando a contribuição pela assinatura do Termo de Consentimento Livre e Esclarecido.

Para termos acesso às representações, é necessário lidar com dados de natureza qualitativa, o que garante o processo de busca de significados e a integridade dos mesmos. Assim, como afirmam Roazzi, Federicci e Carvalho (2002, p. 182):

\footnotetext{
Sabemos que os procedimentos de investigação que privilegiem aspectos qualitativos permitem uma maior aproximação da visão de mundo dos sujeitos. O foco de interesse do pesquisador está, de maneira geral, nas formas como os indivíduos pensam, sentem e se comportam com relação a importantes fatos e experiências da vida cotidiana.
}

Nesse sentido, para identificar as representações dos licenciandos, partimos do pressuposto de que uma representação envolve múltiplos elementos. Por isso, as informações que nos foram reveladas por intermédio dos instrumentos utilizados foram organizadas e 
articuladas por meio da técnica de triangulação de dados. Essas informações foram tratadas com base na análise de conteúdo, conforme sugere Laurence Bardin (2010).

\section{RESULTADOS E DISCUSSÃO}

\subsection{Adequação das teorias de aprendizagem quanto à epistemologia do conceito de gene apresentado}

A análise da primeira situação utilizada no levantamento de informações permite concluir que houve predominante discordância dos licenciandos em relacionar o conceito de gene apresentado ao pensamento indutivista, sendo que a maioria dos discentes $(69,6 \%)$, segundo a Escala Likert, atribuiu as classificações 1 ou 2.

Contudo, houve considerável alinhamento por parte dos licenciandos em considerar o modelo empirista como sendo o mais adequado para explicar o conceito de gene, de maneira que 18 alunos (78,3\%) atribuíram as classificações 4 ou 5 da escala de concordância.

A teoria construtivista de aprendizagem foi considerada pela maioria dos participantes como indiferente na contribuição da formulação do conceito de gene. Diante desses resultados, evidencia-se o enraizado perfil empirista das aulas de Ciências, em que o conhecimento é simplesmente descoberto, mesmo em situações que visam apenas reproduzir experimentos tidos como "cruciais".

\subsection{Planejamento de aulas para o ensino do conceito de gene}

A fim de possibilitar uma discussão que articule os planos de aula solicitados nas situações 2 e 4, passaremos agora a analisá-los juntos.

Os planos de aula apresentados foram caracterizados quanto à natureza da metodologia utilizada; quanto à apresentação do conceito de gene aos alunos (e o momento em que fora apresentado); e, ainda, quanto ao levantamento das concepções prévias dos discentes. Esses dados estão apresentados na tabela 1 e permitiram a comparação com os planos de aula desenvolvidos 
pelos mesmos sujeitos, quando solicitados para o fazerem, em um segundo momento, considerando, agora, os pressupostos que conheciam sobre a teoria construtivista de aprendizagem.

Conforme pode ser visto na tabela 1, é explícita a predominância de propostas de aulas práticas pelos licenciandos nos dois tipos de planos de aula propostos. Além desse aspecto, podemos ainda destacar que, em ambos os tipos de planos de aula propostos pelos licenciandos, houve relevante predominância de fragmentação das atividades da aula em momentos distintos, marcados pela formulação de hipóteses, seguidos pela comprovação das mesmas, procedida pela apresentação do conceito trabalhado no final das atividades propostas nos planos de aula.

Com base nessas evidências, recortamos trechos dos planos de aula propostos pelos licenciandos na situação 2 para destacar a influência empirista na abordagem educativa:

[...] No final da experiência, o DNA [Ácido Desoxirribonucleico] será precipitado e ficará em forma de nuvem, podendo ser visualizado pelos alunos, que saberão como o DNA é de verdade. (S1).

[...] Ao fim da aula prática, os alunos poderão ver o DNA no tubo de ensaio $e$, se quiserem, também poderão 'pescar' o DNA com um palito. (S4).

[...] Após os alunos fazerem a aula prática, na qual farão um modelo de DNA com canudinhos coloridos, será mostrado um vídeo, para que todos conheçam a função dos genes. (S6).

A aula será encerrada com a exposição de um modelo didático que mostra a estrutura dos genes dentro do DNA. (S13).

Como pode ser observado na tabela 1 , adiante, houve uma tendência entre os sujeitos em levantarem as concepções prévias dos alunos como aspecto central no planejamento de aula construtivista.

Os licenciandos abordam os conhecimentos prévios dos estudantes, mas não os consideram no momento de apresentarem o conceito estudado, conforme destacado nos trechos apresentados à frente:

A aula terá início com a discussão entre os alunos sobre o que eles acham ser gene [...]. Depois, iremos para o laboratório, onde será passado um documentário que mostra o real conceito e as funções de um gene. (S4).

Antes da parte experimental, os alunos escreverão o que eles entendem por gene. Depois da parte prática, todos poderão corrigir suas respostas, anotando o conceito correto de gene no caderno. (S18). 
No começo da aula, os alunos, dispostos em círculo, participarão de um debate sobre o que eles sabem sobre gene [...]. Cada um deve dar um exemplo [...]. Ao término da aula, o professor deverá passar no quadro o verdadeiro conceito de gene para que não restem dúvidas. (S21).

A aula começaria com perguntas aos alunos sobre o que são os genes e sobre qual é papel deles na hereditariedade. Depois de assistirem ao vídeo, os alunos poderão discutir com o professor, que irá revelar o conceito de gene aos alunos, dando exemplos de herança, como cor do cabelo e dos olhos, capacidade de enrolar a língua, forma do rosto, etc. (S22).

Tabela 1 - Características dos planos de aula quanto à metodologia, momento da apresentação do conceito e abordagem das concepções prévias dos alunos nos diferentes modelos de plano de aula apresentados

\begin{tabular}{ccccccc}
\hline \multirow{2}{*}{ Sujeito } & \multicolumn{2}{c}{ Plano de aula } & \multicolumn{2}{c}{ Plano de aula construtivista } \\
\cline { 2 - 6 } S1 & Metodologia & Conceito & C.P. & Metodologia & Conceito & C.P. \\
S2 & Prática & Final & Não & Prática & Final & Sim \\
S3 & Expositiva & N.A. & Não & Expositiva & Final & Sim \\
S4 & Prática & N.A. & Não & Prática & N.A. & Não \\
S5 & Prática & N.A. & Não & Prática & Final & Sim \\
S6 & Expositiva & Final & Não & Expositiva & Final & Não \\
S7 & Prática & Final & Não & Prática & Final & Sim \\
S8 & Expositiva & Início & Não & Expositiva & Início & Não \\
S9 & Prática & N.A. & Sim & Expositiva & Final & Sim \\
S10 & Expositiva & Início & Não & Prática & Final & Sim \\
S11 & Expositiva & Início & Não & Expositiva & N.A. & Sim \\
S12 & Prática & Final & Não & Prática & Início & Sim \\
S13 & Prática & Final & Não & Expositiva & Início & Não \\
S14 & Prática & Final & Sim & Prática & Final & Sim \\
S15 & Prática & Final & Não & Prática & Final & Sim \\
S16 & Expositiva & Início & Não & Expositiva & Início & Sim \\
S17 & Prática & Final & Não & Prática & N.A. & Sim \\
S18 & Prática & N.A. & Não & Prática & Final & Sim \\
S19 & Prática & Final & Sim & Prática & Final & Sim \\
S20 & Prática & Início & Não & Prática & Início & Não \\
S21 & Expositiva & Final & Sim & Prática & Final & Não \\
S22 & Prática & N.A. & Não & Expositiva & Final & Sim \\
\hline
\end{tabular}

Fonte: Elaboração própria (2016).

Nota: A metodologia utilizada foi categorizada em Expositiva (expositiva-dialogada) e Prática. A apresentação do conceito foi categorizada em Início (conceito apresentado no início da aula), Final (conceito apresentado no fechamento da aula) ou N.A. (conceito não foi apresentado no plano de aula). O levantamento das concepções prévias dos alunos foi classificado em Sim (levanta as concepções prévias) e Não (não levanta as concepções prévias).

Merece destaque o plano de aula do licenciando S13, que, dentre as principais metodologias propostas, apontou: "distribuição de recortes de artigos de revistas que falem sobre gene, transgênicos, melhoramento genético e clonagem para que os alunos possam entender melhor o assunto", "apresentação do filme Gattaca", "discussão em grupos sobre o que os alunos entendem por gene" e "formulação junto com o professor de um conceito de gene". 
Conceitos referentes a processos ou estruturas não observáveis, como o de gene, são difíceis de serem trabalhados sob uma abordagem prática ou experimental, especialmente por requerer laboratórios sofisticados e demandar muito tempo. Outro aspecto a ser destacado no tocante a conceitos que são produtos da Ciência moderna consiste no fato de os alunos não apresentarem concepções a respeito de um dado modelo conceitual, fruto das recentes tecnologias. Por exemplo: os discentes conhecem que algumas características são transmitidas dos pais para os filhos e que essas características possivelmente foram passadas aos seus pais pelas gerações anteriores, no entanto não apresentam ideias a respeito de como isso ocorre na formação dos gametas nem de como algumas características são herdadas em lugar de outras.

\subsection{A educação construtivista na concepção dos licenciandos}

Os licenciandos deste estudo foram convidados a descrever o que entendem por educação construtivista na terceira situação da coleta de dados. Alguns deles enfatizaram que o ensino construtivista é resultado da ação do professor em apresentar novos conhecimentos aos educandos, sem ignorar ou desconsiderar os conhecimentos prévios deles. Os licenciandos S13 e S16, respectivamente, afirmam que:

[...] na educação construtivista, é bom que o professor saiba o que o aluno conhece sobre o tema, para que, em cima disso, possa ensinar de forma com que não confunda o aluno sobre o que ele já sabe e mude sua opinião, mas sim que amplie seu conhecimento com novas informações.

No ensino construtivista, o professor avalia o conhecimento dos alunos e pode complementá-lo, porém explicando de forma mais científica.

As concepções dos licenciandos S13 e S16 podem ser analisadas de forma a considerar que a aprendizagem do conceito de gene, do ponto de vista da comunidade científica, está relacionada a esse processo de enculturação que permite ao professor (re)negociar as concepções dos alunos.

A maior parte dos licenciandos compartilha a ideia de valorização da interação aluno/professor, levantando as concepções prévias, mas não de forma a (re)negociar significados, pois eles afirmam que o conhecimento científico deve substituir o conhecimento prévio. Lançamos mão de algumas falas para exemplificar essa categoria: 
A educação construtivista consiste em levantar os conhecimentos que os alunos apresentam entre si, cabendo ao professor contribuir para transformar a linguagem dos alunos em linguagem científica. (S9).

No ensino construtivista, o professor deve lapidar o conhecimento do aluno, tornando-o mais adequado e saindo do senso comum. (S12).

\section{AS TEORIAS DA APRENDIZAGEM E A PROBLEMÁTICA DA FORMAÇÃO DE PROFESSORES DE CIÊNCIAS/BIOLOGIA: CONTRIBUIÇÕES PARA UMA PRÁTICA PEDAGÓGICA VOLTADA PARA $O$ PLURALISMO METODOLÓGICO}

As análises das classificações quanto ao nível de adequação das teorias de aprendizagem em relação à formulação do conceito de gene apresentado e dos planos de aula dos licenciandos revelam o predomínio do empirismo como teoria de aprendizagem que melhor representa as situações de ensino de temas relacionados às Ciências, especialmente de conceitos abstratos como o de gene.

Esse resultado vai ao encontro do que Regina Maria Rabello Borges (2007) sugere. Segundo a autora, as tentativas de compreensão e explicação de fenômenos nas aulas de Ciências são realizadas a partir da observação e da realização de procedimentos que precedem a formulação de teorias. Essa forma de trabalhar a experimentação tem influência empirista, na medida em que pressupõe a objetividade e a neutralidade da observação, não considerando (ou até ignorando) que as ideias e os conhecimentos prévios tenham influência nas observações realizadas.

Assim, Borges (2007) e Driver et al. (1999) defendem que o enfoque epistemológico das aulas práticas experimentais nas aulas de Ciências depende da concepção do professor, de modo que a experimentação, por si mesma, não pode ser rotulada de construtivista ou empirista. Para esses autores, um professor consciente das diferentes interpretações possíveis durante a realização de um experimento em aula e capaz de relacioná-las aos conhecimentos prévios dos alunos não será empirista.

Conforme mostram os resultados, para alguns licenciandos, o conhecimento científico deve substituir o não científico. Essa representação de valorização da mudança conceitual como estratégia de ensino é criticada por Mortimer (2000), pois, consoante o autor, os indivíduos não abandonam concepções anteriores ao serem apresentados a concepções novas. 
Nesse sentido, a noção de perfil conceitual proposta por Mortimer (1996) permite entender que as ideias dos estudantes em sala de aula não são substituídas por ideias científicas, mas evoluem juntas, podendo conviver e ser empregadas conforme forem convenientes ao aluno.

Os processos que conduzem à aprendizagem podem seguir caminhos diversos, seja pela via da mudança conceitual, formação de perfis conceituais ou construção de conhecimentos sem status de concepção. Contudo, esses processos podem, de acordo com Bastos et al. (2004), ser afetados pelo fenômeno da distorção dos enunciados científicos, atribuindo importantes consequências para o ensino, uma vez que, para uma compreensão satisfatória das ideias científicas, serão exigidas etapas de construção de significados, checagem e retificação desses significados pelo estabelecimento de relações que estimulem a atividade mental dos discentes.

Paralelamente, a representação apresentada por alguns licenciandos, conforme mostrado anteriormente, de que o ensino construtivista se restringe a lançar mão das concepções prévias dos estudantes, sem considerá-las efetivamente nos processos de ensino-aprendizagem, retrata a representação rotulada de "método" que a teoria construtivista recebeu ao ser entendida como defensora da ideia de que, para a construção da realidade, bastam crenças e/ou experiências dos aprendizes.

$\mathrm{Na}$ ausência de concepções prévias, não faz sentido, consoante Bastos et al. (2004), a proposta de ensino por mudança conceitual. De acordo com os mesmos autores, situações como essa, em que as condições para a realização de experimentos e concepções prévias são escassas, requerem que modelos de ensino realizados por metodologias práticas e/ou experimentais sejam adaptados ou substituídos, como proposto pelo licenciando S13.

Michael Matthews (2000) sugere que a falha do construtivismo advém de seu embasamento ingênuo nas explicações empiricistas sobre o conhecimento, apontando o problema para o que ele denomina "dilema da evidência", em que os construtivistas necessitam recorrer à evidência para sustentar a teoria, mas não podem permitir que a evidência seja objetiva e independente do conhecimento teórico. Diante disso, o construtivismo, segundo o mesmo autor, "[...] esconde uma porção de trivialidades educacionais e tem mais em comum com um jargão do que com uma teoria desenvolvida" (MATTHEWS, 2000, p. 270).

Com base nas críticas feitas aos pressupostos epistemológicos construtivistas e à banalização de seu conceito, tem sido proposto o pluralismo metodológico para o ensino das 
Ciências, tomando de volta os ideais de anarquismo metodológico proposto por Paul Feyerabend (BASTOS et al., 2004; CARVALHO, 2005).

É necessário esclarecer que as críticas centrais ao construtivismo, compartilhadas pelos que defendem uma proposta pedagógica pluralista, estão centradas no entendimento de que os ideais construtivistas também são limitados, assim como ocorre nas demais teorias de aprendizagem às quais o construtivismo se opõe.

Com base nas representações de alguns dos licenciandos, que apresentam a ideia de que, no ensino construtivista, os alunos devem ter seus conhecimentos prévios considerados e o professor deve atuar de forma a complementar o conhecimento dos discentes pela apresentação de conceitos compartilhados pela comunidade científica, coadunamos com Driver (1999) e Mortimer (1996), ao entender que a Prática de Ensino de Ciências envolve um processo de enculturação, caracterizado pela socialização das práticas da comunidade científica e de suas interpretações nos resultados de experimentos ainda distantes da realidade dos estudantes.

Assim, as discussões recentes entre os autores da área de educação científica têm criticado a equivocada leitura das teorias de aprendizagem, que têm dado importância a uma exaustiva utilização de estratégias de ensino centradas unicamente no aluno. Essas discussões apontam para a não fixação dos métodos de ensino a sistemas rígidos e limitados, mas para o que tem sido chamado "pluralismo metodológico".

Quando defendemos que o Ensino de Ciências/Biologia deve ser estruturado com o objetivo de possibilitar ao educando uma aprendizagem significativa de conceitos científicos, estamos considerando esses conceitos como representações da compreensão do mundo natural.

Desse modo, considerados os posicionamentos de ordem teórica discutidos anteriormente, assim como também algumas colocações de ordem prática que foram originadas da análise das informações levantadas, cabe aqui enfatizar, mesmo que de forma breve, que a discussão acerca da mudança conceitual deve levar em consideração a variabilidade de condições e possibilidades presentes no contexto da sala de aula, que, em última análise, influenciam as decisões do ensino, muitas vezes tomadas instantaneamente.

Nesse sentido, é evidente que o objetivo principal da abordagem pluralista não consiste em substituir um conjunto de regras metodológicas por outro conjunto de forma semelhante, 
antes, porém, trata-se de argumentar, num sentido ampliado, que modelos e metodologias de aprendizagem têm restrições e não podem ser utilizados de modo genérico.

A educação científica e os métodos de ensino-aprendizagem a ela vinculados não devem, portanto, estar fixos a sistemas de interpretação rígida. Ao contrário, é necessário que os professores sejam críticos e abertos à adoção de experiências inovadoras, considerando que, quanto mais rico e variado for o ambiente de ensino, maiores são as possibilidades de sucesso no desenvolvimento de uma aprendizagem significativa por parte dos alunos.

À guisa de conclusão, entendemos que ensinar Ciências extrapola os limites da experimentação e de metodologias sistematizadas. Trata-se mais de uma questão de propor possibilidades aos educandos de abstração de conceitos e modelos que devem ser entendidos como representações ou teorizações dos fenômenos da natureza.

\section{REFERÊNCIAS}

BARDIN, L. Análise de conteúdo. Lisboa: 70, 2010.

BASTOS, F. et al. Da necessidade de uma pluralidade acerca do processo de ensino e aprendizagem em Ciências: revisitando os debates sobre o construtivismo. In: NARDI, R.; BASTOS, F.; DINIZ, R. E. S. (Org.). Pesquisas em ensino de Ciências: contribuições para a formação de professores. 5. ed. São Paulo: Escrituras, 2004. p. 9-55. (Educação para a Ciência).

BORGES, R. M. R. Em debate: cientificidade e educação em Ciência. 2. ed. Porto Alegre: PUCRS, 2007.

CARVALHO, M. Construtivismo, pluralismo metodológico e formação de professores para o ensino de Ciências Naturais. Semina: Ciências Biológicas e da Saúde, Londrina, v. 26, n. 2, p. 83-94, 2005.

DRIVER, R. et al. Construindo conhecimento científico na sala de aula. Química Nova na Escola, São Paulo, n. 9, p. 31-40, 1999.

LÜDKE, M.; ANDRÉ, M. E. D. A. Pesquisa em educação: abordagens qualitativas. 9. ed. São Paulo: EPU, 1986.

MARCONI, M. D. A.; LAKATOS, E. M. Técnicas de pesquisa: planejamento e execução de pesquisas, amostragens e técnicas de pesquisas, elaboração, análise e interpretação de dados. 3 . ed. São Paulo: Atlas, 1996. 
MATTHEWS, M. Construtivismo e o ensino de Ciências: uma avaliação. Caderno Catarinense de Ensino de Física, Florianópolis, v. 17, n. 3, p. 270-294, 2000.

MORETTO, P. V. Construtivismo: a produção do conhecimento em aula. Rio de Janeiro: DP\&A, 1999.

MORTIMER, E. F. Construtivismo, mudança conceitual e ensino de Ciências: para onde vamos? Investigações em Ensino de Ciências, Porto Alegre, v. 1, n. 1, p. 20-39, 1996.

MORTIMER, E. F. Linguagem e formação de conceitos no ensino de Ciências. Belo Horizonte: UFMG, 2000.

OSTERMANN, F. A epistemologia de Kuhn. Caderno Catarinense de Ensino de Física, Florianópolis, v. 13, n. 3, p. 184-196, 1996.

PRAIA, J. F.; CACHAPUZ, A. F. C.; GIL-PÉREZ, D. Problema, teoria e observação em Ciência: para uma reorientação epistemológica da educação em Ciência. Ciência e Educação, Bauru, v. 8, n. 1, p. 127-145, 2002.

REGNER, A. C. K. P. Feyerabend e o pluralismo metodológico. Caderno Catarinense de Ensino de Física, Florianópolis, v. 13, n. 3, p. 231-247, 1996.

ROAZZI, A.; FEDERICCI, F. C. B.; CARVALHO, M. R. A questão do consenso nas representações sociais: um estudo do medo entre adultos. Psicologia: teoria e pesquisa, Brasília, DF, v. 18, n. 2, p. 179-192, 2002.

SILVEIRA, F. L. A filosofia da Ciência de Karl Popper: o racionalismo crítico. Caderno Catarinense de Ensino de Física, Florianópolis, v. 13, n. 3, p. 197-218, 1996a.

SILVEIRA, F. L. A metodologia dos programas de pesquisa: a epistemologia de Imre Lakatos. Caderno Catarinense de Ensino de Física, Florianópolis, v. 13, n. 3, p. 219-230, 1996b.

Recebido em 21 de julho de 2016.

Aceito em 21 de setembro de 2016. 